\title{
PENINGKATAN SIKAP BERSAHABAT/ KOMUNIKATIF DAN PRESTASI BELAJAR PADA TEMA 8 DAERAH TEMPAT TINGGALKU MENGGUNAKAN MODEL PROBLEM BASED LEARNING DENGAN BANTUAN MEDIA GAMBAR SERI
}

\author{
Bayu Adji Permana, Pamujo, Badarudin* \\ SDN 2 Sokaraja Tengah, Banyumas, Indonesia \\ Universitas Muhammadiyah Purwokerto, Purwokerto, Indonesia \\ *badar_ump@yahoo.ac.id
}

\begin{abstract}
Background of this research is the low communicative friendly attitude and learning achievement of students. This study aims to improve the friendliness / communicative attitude and learning achievement of students through the Problem Based Learning (PBL) model with the help of serial image media. This classroom action research is carried out in 2 (two) cycles, each cycle consisting of two meetings with each meeting one lesson plan. This research consists of stages of planning, action, observation, and reflection. The subjects of this study were forth grade students, consist of 13 male students and 18 female students. The data collection tool uses evaluation tests, teacher activity sheets, friendly/communicative attitude observation sheets of students as well as students' friendly/communicative attitude scale sheets. The results of the improvements that occur can be seen in each cycle. The results of this study indicated that the use of the Problem Based Learning (PBL) model with the help of serial image media can improve friendliness / communicative attitudes and learning achievements of the theme students of the 8 areas where I live in the fourth grade students of SD Negeri 2 Sokaraja Tengah Sokaraja District, Banyumas.
\end{abstract}

Keywords: communicative attitude, achievement, Problem Based Learning

\begin{abstract}
Abstrak. Latar belakang penelitian ini adalah rendahnya sikap bersahabat komunikatif dan prestasi belajar peserta didik. Penelitian ini bertujuan untuk meningkatkan sikap bersahabat/ komunikatif dan prestasi belajar peserta didik melalui model Problem Based Learning (PBL) dengan bantuan media gambar seri. Penelitian tindakan kelas ini dilaksanakan dalam 2 (dua) siklus, masing- masing siklus terdiri dari dua pertemuan dengan masing-masing pertemuan satu rencana pembelajaran. Penelitian ini terdiri dari tahapan perencanaan, tindakan, observasi dan refleksi. Subjek Penelitian ini adalah peserta didik Kelas IV yang berjumlah 31 peserta didik yang terdiri dari 13 peserta didik laki-laki dan 18 peserta didik perempuan. Alat pengumpulan data menggunakan tes evaluasi, lembar aktivitas guru, lembar observasi sikap bersahabat/ komunikatif peserta didik serta lembar skala sikap bersahabat/ komunikatif peserta didik. Hasil peningkatan yang terjadi dapat dilihat pada setiap siklusnya. Hasil penelitian ini menunjukan bahwa penggunaan model Problem Based Learning (PBL) dengan bantuan media gambar seri dapat meningkatkan sikap bersahabat/ komunikatif dan prestasi belajar peserta didik tema 8 daerah tempat tinggalku pada peserta didik kela IV SD Negeri 2 Sokaraja Tengah Kecamatan Sokaraja, Banyumas.
\end{abstract}

Kata Kunci: Sikap Bersahabat, Prestasi Belajar, Problem Based Learning 


\section{LATAR BELAKANG}

Pendekatan pembelajaran berbasis tematik atau yang lebih dikenal dengan tematik integratif merupakan pendekatan pembelajaran yang mengintegrasikan berbagai kompetensi dari berbagai mata pelajaran dalam berbagai tema. Pendekatan ini dimaksudkan agar peserta didik tidak belajar secara pasif sehingga pembelajaran yang dialaminya memberikan makna yang utuh pada peserta didik seperti yang tercermin pada berbagai tema yang tersedia. Pengetahuan yang utuh merupakan hasil bentukan peserta didik itu sendiri. Peserta didik membentuk pengetahuannya melalui interaksi dengan lingkungan, bukan bentukan dari orang lain. Pembelajaran terpadu ini didefinisikan sebagai pembelajaran yang menghubungkan berbagai gagasan, konsep, keterampilan, sikap, dan nilai, baik antar mata pelajaran maupun dalam satu mata pelajaran. Majid, Abdul \& Chaerul Rochman (2015: 2) menyatakan bahwa orientasi pembelajaran dalam konteks kurikulum 2013 adalah untuk menghasilkan insan Indonesia yang produktif, kreatif, inovatif, dan efektif melalui penguatan sikap (tahu mengapa), keterampilan (tahu bagaimana), dan pengetahuan (tahu apa).

Pembelajaran yang menarik dapat memberikan pengaruh kepada peserta didik untuk berpartisipasi aktif dalam proses pembelajaran. Secara tidak langsung hal tersebut dapat meningkatkan daya ingat yang berkepanjangan dari peserta didik, serta dalam kegiatan belajar mengajar seorang guru perlu mengadakan pembelajaran yang berpusat pada peserta didik karena semakin sering terlibat, maka semakin besar pula kesempatan peserta didik mengalami proses pembelajaran.

Pembelajaran tematik di sekolah pada kenyataannya belum terlaksana dengan baik, masih banyak kendala yang terjadi seperti rendahnya minat belajar peserta didik, kurang menariknya proses pembelajaran, pembelajaran yang masih terpusat pada guru (teacher centered), serta kurang aktifnya peserta didik dalam kegiatan pembelajaran. Kurang aktifnya peserta didik ini terlihat saat pembelajaran berlangsung, hal ini ditunjukkan dengan tidak ada pertanyaan terkait materi pelajaran yang belum diketahuinya, peserta didik hanya diam. Kurang aktifnya peserta didik dalam belajar megakibatkan rendahnya pemahaman terhadap materi-materi pelajaran serta nilai yang diperoleh rendah. Berdasarkan hasil observasi di kelas IV dan wawancara dengan guru wali kelas IV, di peroleh informasi penyebab kegagalan dalam pembelajaran tematik antara lain pembelajaran hanya menggunakan ceramah dan kurang memperhatikan keterlibatan peserta didik. Guru dalam hal ini tidak memperhatikan secara keseluruhan apa yang dilakukan saat pembelajaran, apakah peserta didik memperhatikannya atau tidak. Akibatnya peserta didik menjadi pasif, dari 31 jumlah anak hanya beberapa peserta didik yang menunjukkan keaktifannya dalam mengikuti pembelajaran. Peserta didik yang aktif itu terlihat dengan kemauan yang berani untuk bertanya tentang hal yang belum dipahami secara jelas kepada guru. Secara keseluruhan sikap mereka terhadap pembelajaran tematik kurang antusias sehingga untuk menyampaikan pendapat atau gagasan mereka rendah. Kurangnya antusias pada peserta didik ini terlihat saat ditanya sudah paham atau belum, peserta didik hanya terdiam. Selain itu proses pembelajaran belum menggunakan model dan media pembelajaran secara optimal. Media yang sudah tersedia tidak dimanfaatkan secara maksimal oleh guru dan hanya tersimpan rapi di dalam lemari. Interaksi yang terjadi di kelas lebih banyak didominasi oleh guru. Guru lebih banyak bertanya kepada peserta 
didik dan peserta didik tidak merespons dengan baik sehingga hanya terjadi komunikasi satu arah yaitu antara guru dengan peserta didik.

Melihat kondisi permasalahan yaitu sikap bersahabat/ komunikatif yang masih kurang, tentu hal tersebut akan mempengaruhi prestasi belajar peserta didik yang tergolong masih rendah. Selain itu pula belum adanya media yang menarik sehingga peserta didik merasa bosan dan sulit untuk berpikir sehingga ulangan ataupun ujian yang dilakukan harus diulang agar mencapai nilai yang sesuai KKM. Berdasarkan hasil diskusi dengan guru kelas maka peneliti dan guru kelas sepakat menggunakan model pembelajaran Problem Based Learning (PBL) dengan bantuan media gambar seri pada tema 8 Daerah Tempat Tinggalku. Melalui model Problem Based Learning (PBL) dengan bantuan media gambar seri anak dapat berdiskusi aktif, masing-masing anggota dapat menyampaikan gagasannya. Penggunaan media dalam pembelajaran juga mempengaruhi keberhasilan suatu pembelajaran. Kehadiran media tidak saja membantu pengajar dalam menyampaikan materi ajaranya, tetapi memberikan nilai tambah pada kegiatan pembelajaran. Falahudin (2014: 13) menyatakan bahwa media merupakan salah satu komponen pembelajaran, pemanfaatan media seharusnya merupakan bagian yang harus mendapat perhatian pembelajar dalam setiap kegiatan pembelajaran.

Pembelajaran dengan model Problem Based Learning (PBL) memiliki kelebihan, diantaranya mampu melibatkan peserta didik dalam kegiatan pembelajaran sehingga pengetahuan dapat terserap dengan baik serta menciptakan suasana kondisi yang aktif, memperoleh pengetahuan baru sehingga dapat memantapkan konsep pada peserta didik, dilatih untuk bekerjasama dengan peserta didik lain, mendorong adanya kompetisi dalam kelompok, serta dapat melatih peserta didik untuk belajar menyampaikan pendapat atau argumennya. Berdasarkan latar belakang masalah yang telah dijelaskan, maka rumusan masalah pada penelitian ini adalah: (1) Apakah model pembelajaran Problem Based Learning (PBL) dengan bantuan media gambar seri dapat meningkatkan sikap bersahabat/ komunikatif peserta didik kelas IV SD Negeri 2 Sokaraja Tengah? (2) Apakah model pembelajaran Problem Based Learning (PBL) dengan bantuan media gambar seri dapat meningkatkan prestasi belajar peserta didik kelas IV SD Negeri 2 Sokaraja Tengah?. Penelitian tindakan kelas ini bertujuan untuk: (1) Meningkatkan sikap bersahabat/ komunikatif peserta didik kelas IV SD Negeri 2

Sokaraja Tengah pada tema 8 melalui Model Problem Based Learning (PBL) dengan bantuan media gambar seri. (2) Meningkatkan prestasi belajar peserta didik kelas IV SD Ngeri 2 Sokaraja Tengah pada tema 8 melalui Model Problem Based Learnig (PBL) dengan bantuan media gambar seri.

\section{B. METODODLOGI PENELITIAN}

Penelitian dilakukan di kelas IV SD Negeri 2 Sokaraja Tengah. Sekolah ini berada di Sokaraja, Kecamatan Sokaraja, Kabupaten Banyumas. Alasan peneliti memilih SD Negeri 2 Sokaraja Tengah sebagai tempat penelitian karena peneliti sebelumnya pernah mengamati pembelajaran dan menemukan permasalahan berkaitan dengan sikap bersahabat/ komunikatif dan hasil prestasi belajar dalam pembelajaran tema, yakni masih banyak peserta didik yang mendapatkan nilai di bawah KKM yang telah ditentukan di sekolah tersebut yaitu 71 untuk pelajaran PPkn, IPS, dan Bahasa Indonesia. Hal tersebut membuktikan bahwa hasil belajar peserta didik masih rendah. Teknik yang digunakan peneliti untuk mengumpulkan data ada dua macam, 
yaitu teknik tes dan non tes. Teknik tes berupa tes tertulis yang berbentuk uraian yang dilakukan disetiap akhir pertemuan, sedangkan teknik non tes yaitu observasi guru dan observasi sikap bersahabat/ komunikatif peserta didik yang dilakukan oleh observer menggunakan lembar observasi.

\section{Hasil dan Pembahasan}

1. Peningkatan Sikap Bersahabat/ Komunikatif Peserta Didik

Pada saat Penelitian Tindakan Kelas (PTK) sikap bersahabat/ komunkatif peserta didik diukur dengan menggunakan lembar observasi sikap dan angket skala sikap bersahabat/ komunikatif peserta didik secara individu yang diberikan oleh guru pada siklus I pertemuan I dan siklus II pertemuan II. Wangsa, dkk (2017: 2) menyatakan bahwa sikap bersahabat/ komunikatif peserta didik harus dirangsang dengan pembelajaran yang mampu menggali kemampuan peserta didik yang dimilikinya. Hasil observasi sikap pada siklus I, terdapat peningkatan jumlah peserta didik yang menunjukkan aspek tersebut dengan rata-rata sebesar 2,59 termasuk kategori tidak baik sedangkan pada siklus II peserta didik semakin dilibatkan secara aktif dalam pembelajaran dengan ratarata sebesar 3,76 termasuk kategori baik. Sesuai dengan teori yang dikemukakan oleh Suyadi (2013: 6) pendidikan karakter dapat diartikan sebagai upaya sadar dan terencana dalam mengetahui kebenaran atau kebaikan, mencintainya dan melakukannya dalam kehidupan sehari-hari. Karakter yang seperti inilah yang perlu dikembangkan dalam dunia pendidikan.

Pengunaan model Problem Based Learning (PBL) dengan bantuan media gambar seri berdampak baik pada pembelajaran, terbukti hampir semua peserta didik memahami pembelajaran dengan menggunakan model dengan bantuan media tersebut, peserta didik banyak yang menunjukkan sikap bersahabat/ komunikatif dan terlihat aktif dalam pembelajaran. Majid, Abdul \& Chaerul Rochman (2015: 154) menyatakan bahwa model pembelajaran berbasis masalah merupakan suatu model pembelajaran yang menantang peserta didik untuk belajar bagaimana belajar, bekerjasama secara kelompok untuk mencari solusi dari permasalahan dunia nyata.

Pada saat Penelitian Tindakan Kelas (PTK) sikap bersahabat/ komunikatif peserta didik diukur dengan menggunakan angket sikap bersahabat/ komunikatif secara individu yang diberikan oleh guru pada akhir siklus I pertemuan 1 dan pada siklus II pertemuan 2. Untuk lebih jelas tentang hasil angket sikap bersahabat/ komunikatif peserta didik dapat dilihat Gambar 1.

Gambar 1 menunjukkan skor rata-rata perubahan sikap komunikatif peserta didik. Terjadi peningkatan dari siklus I dan Siklus II dari nilai 3,11 (baik) menjadi 3,73 (sangat baik) yaitu sebesar 0,62. Hal ini tidak terlepas dari harapan yang dicita-citakan Kemendikbud (2017: 7) salah satu kecakapan abad 21 adalah kecakapan berkomunikasi (Comunication Skill). Untuk mempersiapkan itu semua maka dibutuhkan adanya pembiasaan pada setiap peserta didik dalam berbagai jenjang pendidikan, khususnya pendidikan sekolah dasar. Pembiasan yang dilakukan dengan baik dan sungguh-sungguh akan mewujudkan karakter yang kuat sehingga siap menghadapi perubahan zaman.

\section{Peningkatan Prestasi Belajar Peserta Didik}

Prestasi belajar tidak dapat dipisahkan dari kegiatan belajar, karena belajar menunjukan suatu proses, sedangkan prestasi belajar merupakan hasil dari proses belajarnya. Prestasi belajar juga dikemukakan oleh Sudijono (2011:434) 
menyatakan bahwa prestasi dijadikan sebagai salah satu bahan pertimbangan dalam penentuan nilai akhir, sebab prestasi atau pencapaian peserta didik dapat dilambangkan dengan nilai-nilai.

\section{Angket Sikap Bersahabat/ Komunikatif}

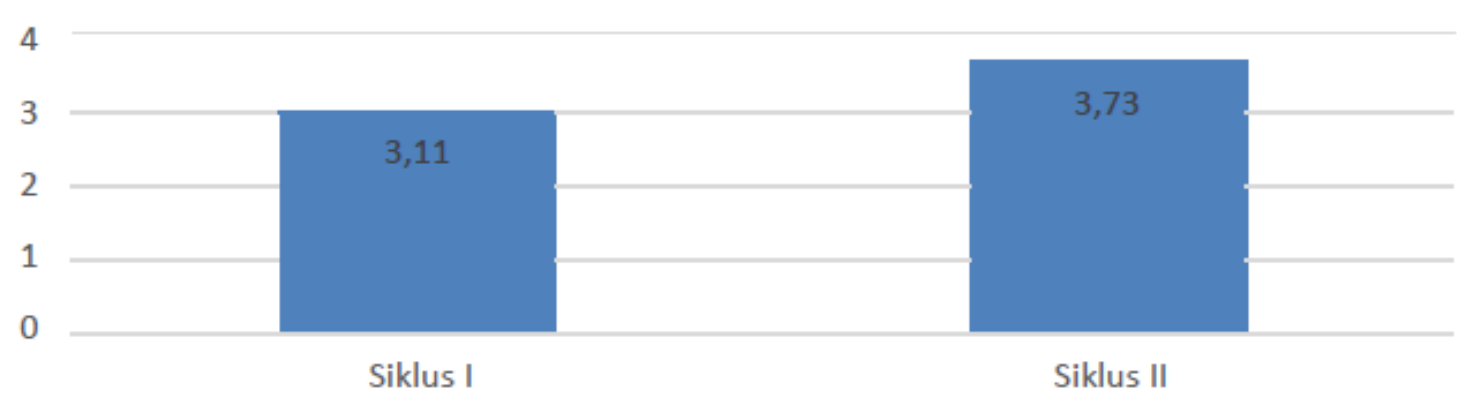

Gambar 1 Histrogram Sikap Bersahabat/ Komunikatif Peserta Didik

Pada pembelajaran siklus I, hasil yang diperoleh peserta didik yang belum tuntas pada pertemuan 1 pada mata pelajaran Bahasa Indonesia sebanyak 14, dan pada pertemuan II pada mata pelajaran Bahasa Indonesia sebanyak 9 peserta didik. Siklus II hasil yang diperoleh peserta didik pada pelajaran Bahasa Indonesia meningkat dengan jumlah peserta didik yang belum tuntas pada pertemuan 1 pada mata pelajaran Bahasa Indonesia sebanyak 5 dan pada pertemuan 2 pada mata pelajaran Bahasa Indonesia sebanyak 5 peserta didik.

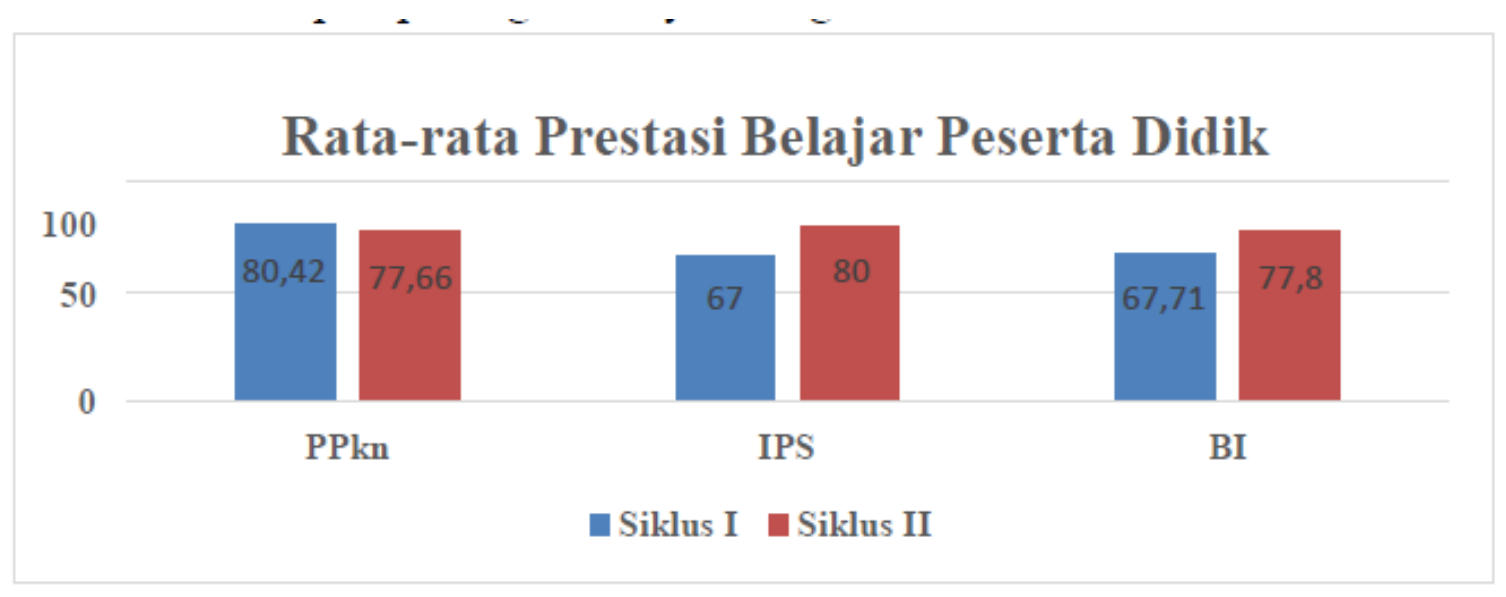

Gambar 2. Histogram Rata-rata Prestasi Belajar Peserta Didik 
Histogram di atas grafik peningkatan nilai rata-rata kelas dari siklus I dan siklus II mengalami peningkatan dengan diperoleh nilai rata-rata kelas siklus I untuk pelajaran PPkn sebesar 80,42, sedangkan siklus II sebesar 77,66, siklus I untuk pelajaran IPS sebesar 67, sedangkan siklus II sebesar 80, siklus I untuk pelajaran Bahasa Indonesia sebesar 67,71, sedangkan siklus II sebesar 77,8.

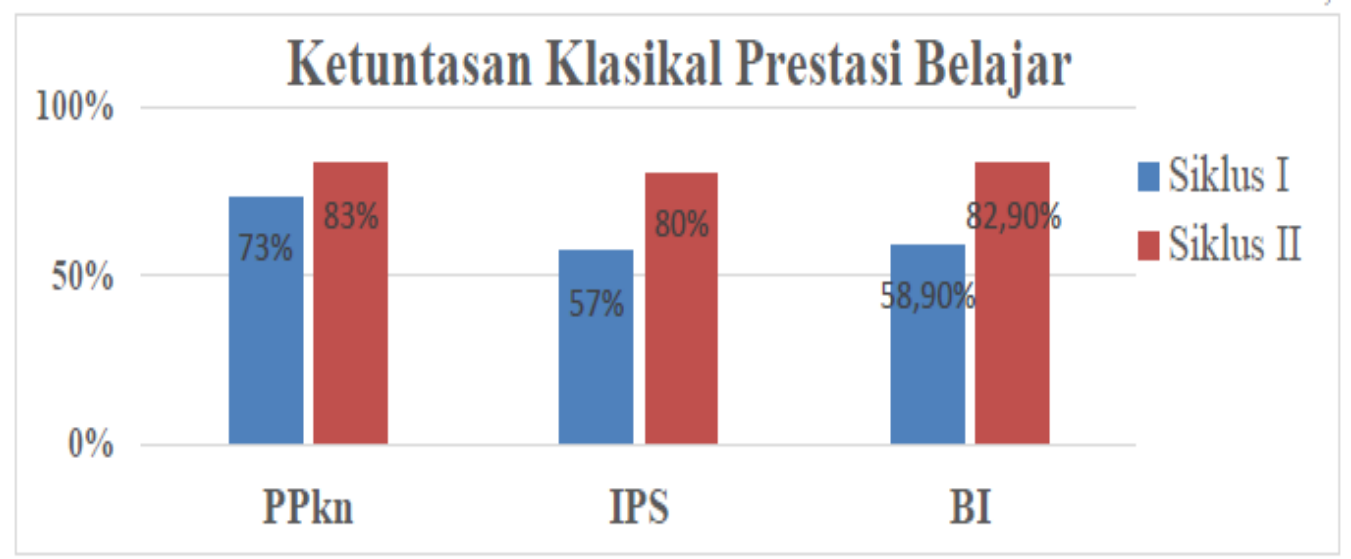

\section{Gambar 3. Histogram Ketuntasan Klasikal Prestasi Belajar Peserta Didik}

Histogram di atas grafik presentase klasikal peningkatan nilai rata-rata kelas dari siklus I dan siklus II mengalami peningkatan dengan diperolehnya nilai pada siklus I pelajaran PPkn sebesar $73 \%$, sedangkan siklus II sebesar 83\%, siklus I pada pelajaran IPS sebesar $57 \%$, sedangkan siklus II sebesar $80 \%$, siklus I pada pelajaran $58,90 \%$, sedangkan siklus II $82,90 \%$. Hasil di atas sesuai dengan pendapat yang dikemukakan oleh Majid, Abdul \& Chaerul Rochman (2015: 154) bahwa model pembelajaran berbasis masalah merupakan suatu model pembelajaran yang menantang peserta didik untuk belajar bagaimana belajar, bekerjasama secara kelompok untuk mencari solusi dari permasalahan dunia nyata.

\section{SIMPULAN DAN SARAN}

Dari penelitian yang dilakukan di SD Negeri 2 Sokaraja Tengah maka dapat disimpulkan bahwa:

1. Penerapan model Problem Based Learning dengan bantuan media gambar seri dalam pembelajaran tematik tema 8 Daerah Tempat Tinggalku dapat meningkatkan sikap bersahabat/ komunikatif peserta didik. Peningkatan ini terlihat tidak hanya dari hasil skala sikap yang diisi oleh setiap peserta didik, tetapi juga dari keaktifan yang menunjukkan sikap bersahabat/ komunikatif peserta didik dalam belajar. Hal tersebut ditunjukan dengan hasil observasi sikap pada siklus I, terdapat peningkatan jumlah peserta didik yang menunjukkan aspek tersebut dengan rata-rata sebesar 2,56 termasuk kategori tidak baik sedangkan pada siklus II peserta didik semakin dilibatkan secara aktif dalam pembelajaran dengan rata-rata sebesar 3,79 termasuk kategori baik dan hasil skala yang diperoleh peserta didik yang mengalami peningkatan yaitu dari siklus I rata-rata 3,11 dengan kriteria baik menjadi 3,73 di siklus II dengan kriteria sangat baik.

2. Penerapan model Problem Based Learning (PBL) dengan bantuan media gambar seri dalam pembelajaran tematik tema 8 Daerah Tempat Tinggalku dapat mengingkatkan prestasi belajar peserta didik. Hal tersebut ditunjukan dengan hasil tes evaluasi yang diperoleh peserta didik yang mengalami peningkatan ketuntasan yaitu dari siklus I ketuntasan klasikal pelajaran PPkn 73\% menjadi 83\% dengan kriteria sangat baik, siklus I ketuntasan klasikal pelajaran IPS $57 \%$ menjadi $80 \%$ dengan kriteria baik, siklus I ketuntasan klasikal pelajaran Bahasa Indonesia $58,90 \%$ menjadi $82,90 \%$ dengan kriteria sangat baik. 
Berdasarkan pada kesimpulan hasil perbaikan pembelajaran dalam Penelitian Tindakan Kelas (PTK) di atas, peneliti menyadari sepenuhnya adanya keterbatasan baik waktu dan tenaga serta kemampuan yang dimiliki oleh peneliti sendiri. Ada beberapa hal yang harus diperhatikan dalam melakukan suatu penelitian pembelajaran di kelas, antara lain:

1. Model pembelajaran Problem Based Learning (PBL) merupakan model yang fleksibel sehingga dapat diterapkan di berbagai bidang pelajaran.

2. Hasil penelitian ini hendaknya digunakan untuk refleksibagi guru, Kepala Sekolah dan orang tua peserta didik.

3. Artikel ini dapat dijadikan sebagai bahan acuan untuk penelitian selanjutnya dengan berbagai pertimbangan dan perbaikan untuk lebih menyempurnakan hasil yang dicapai.

\section{DAFTAR PUSTAKA}

Falahudin, I. 2014. "Pemanfaatan Media dalam Pemebelajaran". Jurnal Lingkar Widyaiswara, Edisi 1 No. 4 diakses pada tanggal 14 november 2017

Kemendikbud. 2017. Panduan Implementasi Kecakapan Abad 21 Kurikulum 2013 di Sekolahh Menengah Atas. Jakarta: Direktorat Jenderal Pendidikan Dasar dan Menengah diakses tanggal 9 Mei 2018

Majid, Abdul \& Chaerul Rochman. 2015.
Pendeketan
Ilmiah
Dalam
Implementasi Kurikulum 2013.
Bandung: PT Remaja Rosdakarya

Sudijono, A. 2011. Pengantar Evaluasi Pendidikan. Jakarta: PT Raja Grafindo Persada

Suyadi. 2013. Srtategi Pembelajaran Pendidikan Karakter. Bandung: PT Remaja Rosdakarya

Wangsa, P G dkk. 2017.’Upaya Meningkatkan Kemampuan Komunikasi dan Pemahaman Konsep Siswa melalui Pembelajaran Inkuiri Dengan bantuan Teknik TSTS. Jurnal Wahana Pendidikan Fisika, Vol. 2, No. 2 diakses pada tanggal 16 Desember 2017 